\title{
Artonin O, a Xanthone Compound from Root Wood of Artocarpus rigida
}

\author{
TATI SUHARTATI ${ }^{1, \star}$, AJENG WULANDARI ${ }^{1}$, \\ JHONS F. SUWANDI ${ }^{2}$, YANDRI ${ }^{1}$ and SUTOPO HADI ${ }^{1}$ \\ 'Department of Chemistry, University of Lampung, \\ J. S. Brojonegoro No. 1 Bandar Lampung Indonesia 35145. \\ ${ }^{2}$ Faculty of Medicine, University of Lampung, \\ Jl. S. Brojonegoro No. 1 Bandar Lampung Indonesia 35145 \\ *Corresponding author E-mail: tati.suhartati@ fmipa.unila.ac.id
}

http://dx.doi.org/10.13005/ojc/320552

(Received: August 12, 2016; Accepted: September 25, 2016)

\begin{abstract}
A xanthone derivative, artonin $\mathrm{O}(1)$, has successfully been isolated from root wood of Artocarpus rigida grown in Lampung, Indonesia. The structure of this compound has been carefully determined by some spectroscopy techniques and based on physical data. The antibacterial activity test on this compound towards Bacillus subtilis, showed that it has medium activity.
\end{abstract}

Keywords: A. rigida, antibacterial activity, artonin O, B. subtilis.

\section{INTRODUCTION}

We have previously reported that from the root bark of $A$. rotunda (Houtt.) Panzer, one of endemic species in Indonesia, obtained from Hutan Raya Bengkulu, has been isolated prenylated flavone, artonin $\mathrm{E}$ as well as three xanthone derivatives, artonin $\mathrm{O}$, artonin $\mathrm{M}$ and cycloartobiloxanthone, and a geranilated flavone, artoindonesianin $\mathrm{L}^{1}$. A. rigida is part of Artocarpus plant which is also endemic in Indonesia, so the chemistry research about this plant is still interesting. Some organic compounds have successfully been isolated from some parts of A. rigida obtained from Keputran Village, Sukoharjo,
Pringsewu Lampung Indonesia. From its root bark, artonin $\mathrm{E}$ has been isolated and it has been shown to have good anticancer and antimalaria activities².

In this work, we reported artonin $\mathrm{O}$ which has been isolated from root wood of $A$. rigida. The antimicrobial activity of this compound has also been tested against $B$. subtillis.

\section{EXPERIMENTAL}

\section{General}

The melting point was determined with Gallenkamp melting poin apparatus and is 
uncorrected. The UV-Vis spectrum was obtained on Agilent Cary 100 spectrometer and the IR spectrum was measured with Agilent Cary 620 FTIR. The ${ }^{1} \mathrm{H}$ and ${ }^{13} \mathrm{C}$ NMR spectra were obtained on Agilent spectrometer with DD2 console system at $500 \mathrm{MHz}$ and $125 \mathrm{MHz}$, respectively. Mass spectrum was measured with Waters mass spectrometer, LCT Premier XE MS. Vacuum liquid chromatography (VLC) was performed using Merck Si-gel 60, thin layer chromatography (TLC) analysis was carried out on pre-coated Si-gel plates (Merck Kieselgel 60 F254, $0.25 \mathrm{~mm}$ ).

\section{Plant collections}

Samples of the root wood of $A$. rigida Blume were collected from Keputran Village, Sukoharjo Pringsewu Lampung and were identified at the Herbarium Bogoriense, Research Centre for Biology, Indonesia Institute of Sciences Bogor, Indonesia and a voucher specimen has been deposited at the herbarium.

\section{Extraction and Isolation}

The powder of root wood of $A$. rigida (3 kg) was extracted exhaustively with $n$-hexane ( $3 \times 10$ $\mathrm{L})$ and a mixture of methanol-ethylacetate (EtOAc) $1: 1$ ( $3 \times 10 L)$. On removal of the solvents by vacuum rotatory evaporator produced methanol/EtOAc extract (127 g). The methanol/EtOAc extract was then fractioned by Si-gel vacuum liquid chromatography (VLC) and was eluted with EtOAc: $n$-hexane with the ratio from $0-100 \%$, to produce 6 main fractions (A-F), A $3.2 \mathrm{~g}$; B $0.6 \mathrm{~g}, \mathrm{E} 7.8 \mathrm{~g}$

Fraction A was then subjected with VLC using Si-gel with eluent of EtOAc: $n$-hexane by increasing the polarity from $10-20 \%$, to produce 5 main fractions based on their TLCs. The fifth fraction $(0.33 \mathrm{~g})$ was purified with VLC (Si gel $60 \mathrm{GF}_{254}$ EtOAc: $n$-hexane 3-20\%) to yield the main compound, artonin $\mathrm{O}$ (compound 1) (29 mg). The fractination of fraction $B$ was performed with the same way using eluent of EtOAc: $n$-hexane $4-20 \%$ to yield 3 main fractions. The fractination of the third fraction $(0.167$ g) with VLC using eluent of EtOAc: $n$-hexane 3-20\%, the red crystal $(4.5 \mathrm{mg})$ was obtained after being recrystallized with EtOAc: $n$-hexane. This crystal has the same retention time (Rf) with compound 1 based on TLC using three eluent systems. Based on TLC, the total amount of compound 1 obtained was 33.5 mg.

\section{Artonin O (1)}

Compound 1 , is found to be red needle crystal with melting point of $203-205^{\circ} \mathrm{C}$ (decomposed). UV (MeOH) $\lambda_{\max } \mathrm{nm}(\log \varepsilon): 202$ (4.6), 254 (4.3), 317

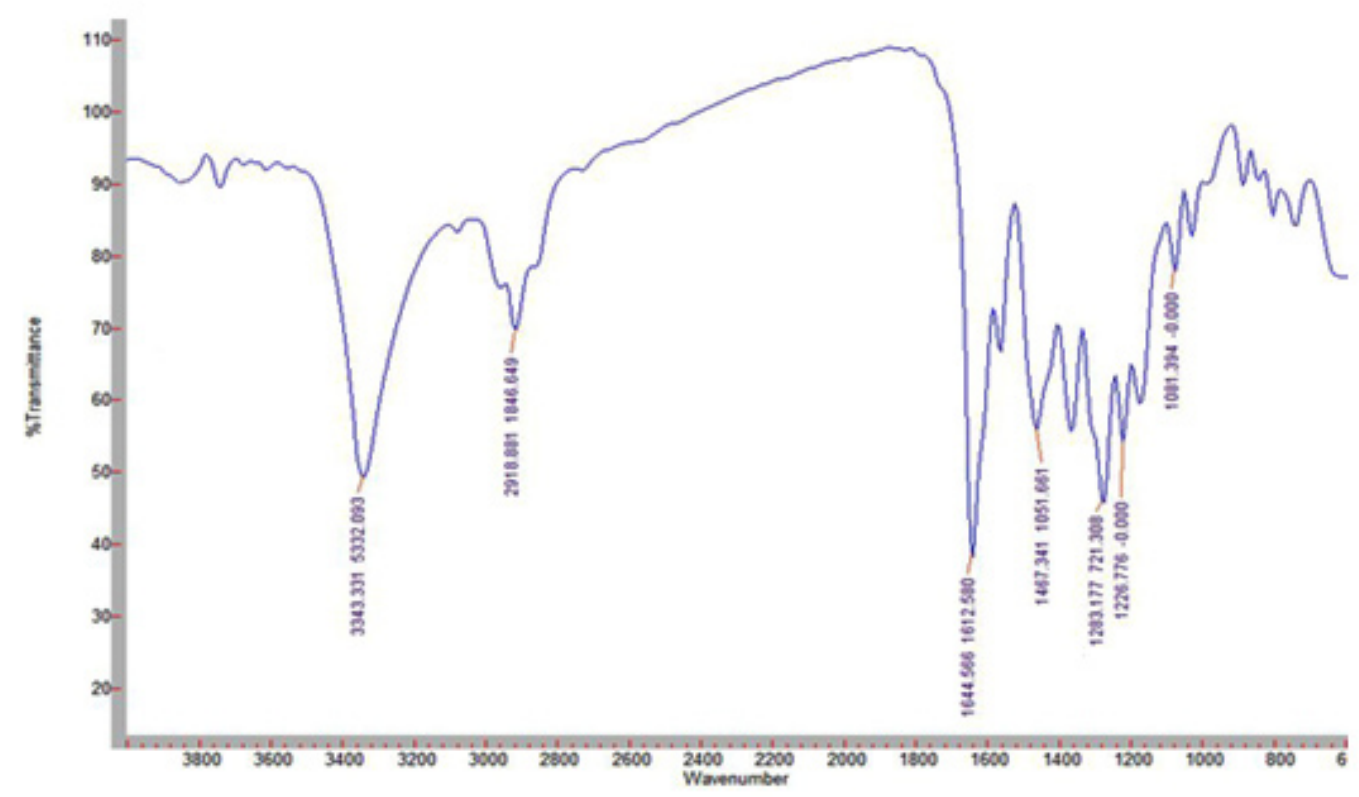

Fig. 1: IR spectrum of isolated compound 1 
(4.2); while on the addition of commonly-used shift reagents, did not change the initial spectrum. The IR (KBr) gave $v_{\text {max. }} \mathrm{cm}^{-1}$ : 3343 (broad), 2918, $1644,1467,1283,1226$, and 1081. HRMS $\mathrm{m} / \mathrm{z}$ (relative intensity): $503.2059\left(\mathrm{M}^{+}+1\right.$, TOF MS ES+ $1.43 e+004$.

${ }^{1} \mathrm{H}$ NMR $\left(\mathrm{CD}_{3} \mathrm{OD}\right) \delta$ (ppm): 1.65; $1.67 ; 1.77$; 1.80 (each for $3 \mathrm{H}, \mathrm{s}, \mathrm{H}-17, \mathrm{H}-22,6 \mathrm{H}$, s, for $\mathrm{H}-18,23$ and $3 \mathrm{H}, \mathrm{s}$, for $\mathrm{H}-13) ; 2.61(1 \mathrm{H}$, dd, $\mathrm{J}=8$ and $17 \mathrm{~Hz}$, $\mathrm{H}-9)$; 3.19 (2H, d, $J=7 \mathrm{~Hz}, \mathrm{H}-19)$; 3.75 (1H, d, $J=$ 8.6 Hz; $\mathrm{H}-10$ ); $4.54 ; 4.75$ (each for $1 \mathrm{H}, \mathrm{s}, \mathrm{H}-12$ ); 5.17 ; 5.21 (each for $1 \mathrm{H}, \mathrm{m}, \mathrm{H}-15$ and $\mathrm{H}-20) ; 6.46(1 \mathrm{H}, \mathrm{s}$, $\mathrm{H}-8)$.

\section{Biological activity}

The antibacterial activity test was performed using paper disc method test.

\section{RESULTS AND DISCUSSION}

\section{Artonin 0}

The UV spectrum of compound 1 gave $\lambda_{\text {max }}$ at 202, 254, and $317 \mathrm{~nm}$ in methanol, indicated the characteristic of flavone compound. The maximum absorbance at $\lambda_{\max } 317 \mathrm{~nm}$ is a characteristic spectrum of flavone which is the electron excitation on cynamoil group in B ring, known as Band I, while the $\lambda_{\text {max }}$ at $254 \mathrm{~nm}$ is characteristic of electron excitation of benzoyl group on A ring known as band II.

Fig. 1 shows the IR spectrum of compound 1. There is a broad band at $3343 \mathrm{~cm}^{-1}$ which is stretch vibration of hydroxyl group bound to hydrogen. The band at $2918 \mathrm{~cm}^{-1}$ is an indication the presence of $\mathrm{C}-\mathrm{H}$ aliphatic. The band at $1644 \mathrm{~cm}^{-1}$ indicates the present of carbonyl group $(\mathrm{C}=\mathrm{O})$ conjugated with $\mathrm{C}=\mathrm{C}$ bond. The band at $1467 \mathrm{~cm}^{-1}$ is the present of $\mathrm{C}=\mathrm{C}$ aromatic, while the bands at 1283, 1226, 1081 $\mathrm{cm}^{-1}$ are indication of stretch of C-O.

The IR spectrum of 1 indicated the similarity with spectrum from standard artonin $O$. It can be seen by comparing the IR spectra of 1 and the standard in literature (Table 1).

The IR spectrum of compound 1 with band at $3343,2918,1644,1467,1283,1226$, and 1081 $\mathrm{cm}^{-1}$, and UV spectrum (MeOH) $\lambda_{\max } 202,254$, and $317 \mathrm{~nm}$ showed a similar absorption style to artomunoxantrione epoxide (3) ${ }^{4}$, artobiloxanthone $(4)^{5}$, or artonin $\mathrm{N}(5)^{6}$ which shows that compound 1 also contains xanthonoid chromophore ${ }^{5}$.

To strengthen the analysis of the structure of the compound isolated, the ${ }^{13} \mathrm{C}$ and ${ }^{1} \mathrm{HNMR}$ were taken and the spectra of 1 obtained are presented

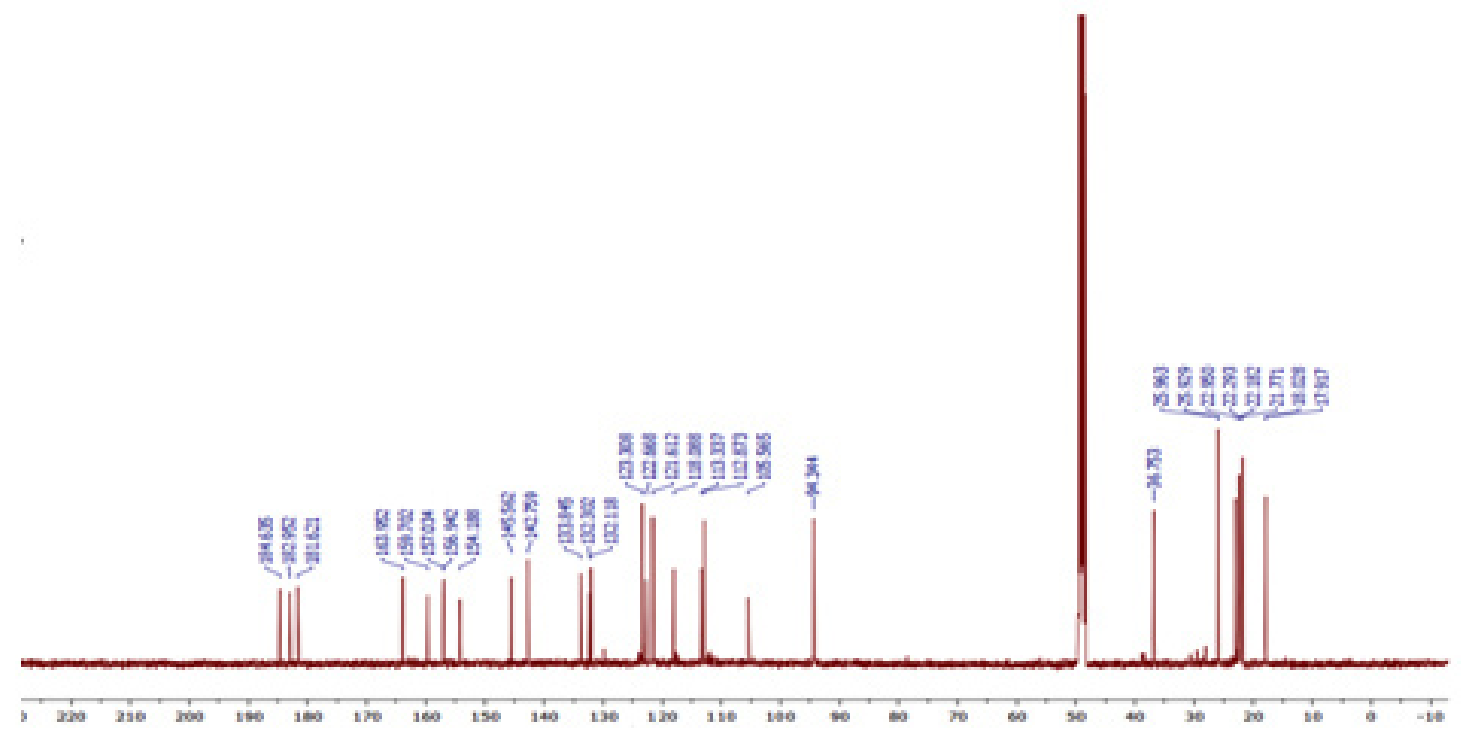

Fig. 2: ${ }^{13} \mathrm{C}$ NMR spectrum of isolated compound 1 
Table 1: The comparison of IR data of compound 1

(A) and standard (B) ${ }^{3}$

\begin{tabular}{cc}
\hline \multicolumn{2}{c}{$\mathbf{I R}(\mathbf{K B r})\left(\begin{array}{c}\left.\mathbf{c m}^{-1}\right) \\
\mathbf{B}\end{array}\right.$} \\
\hline 3343 & 3350 \\
2918 & 2962 \\
1644 & 1647 \\
1467 & 1470 \\
1283 & 1283 \\
1226 & 1225 \\
1081 & 1080 \\
\hline
\end{tabular}

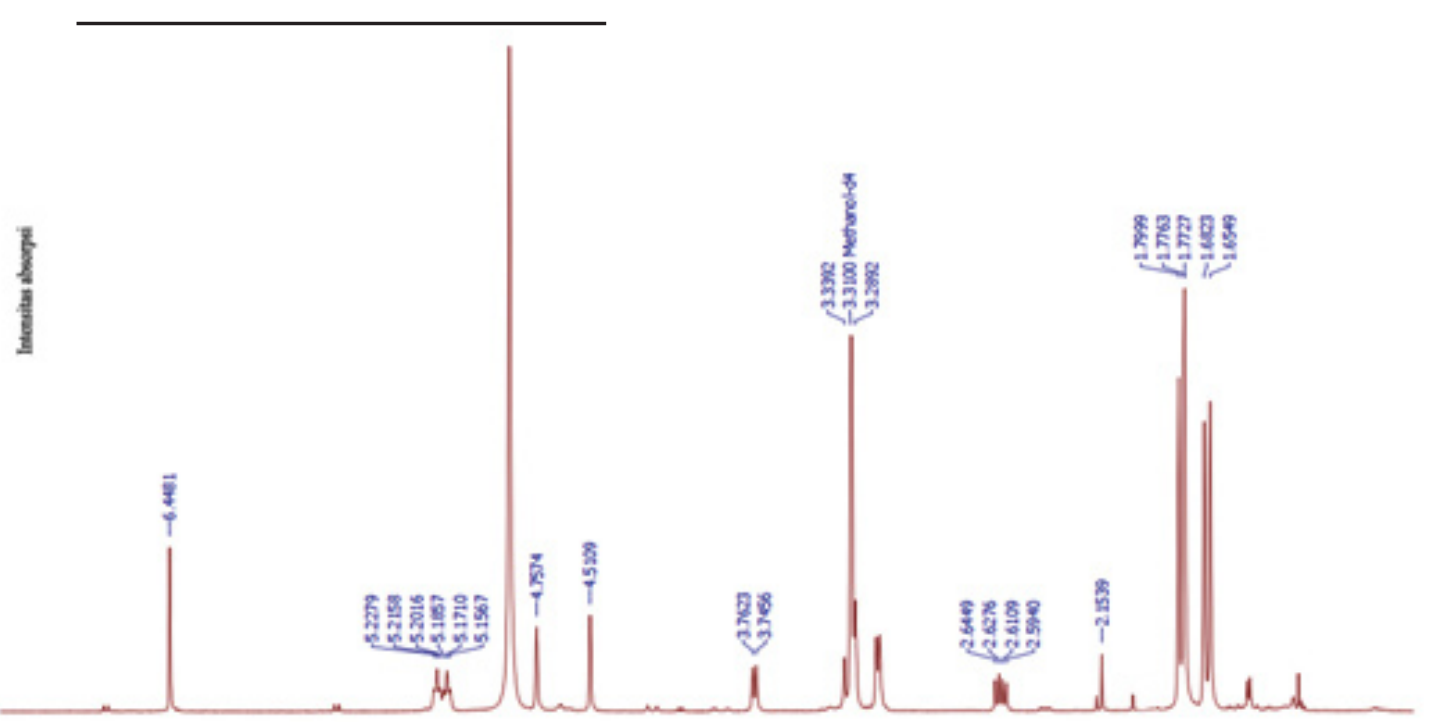

in Fig. 2 and 3, respectively. ${ }^{13} \mathrm{C}$ NMR spectrum of 1 shows 30 carbon signals. Based on these chemical shifts, at $\delta>100 \mathrm{ppm}$, there are 21 carbon signals which indicate the presence of hybrid orbital $\mathrm{sp}^{2}$ and there are 9 carbon signals at $\delta<100 \mathrm{ppm}$ indicating the presence of hybrid orbital $\mathrm{sp}^{3}$.

Each carbon signals at $\delta 181.6 ; 182.9$; and $184.6 \mathrm{ppm}$ are assigned as carbon from carbonyl group, where the signal at $181.6 \mathrm{ppm}$ is known as C signal of carbonyl from C-4 of a flavone compound, while the other two carbon signals are assigned as carbon from carbonyl group of quinoid structure.
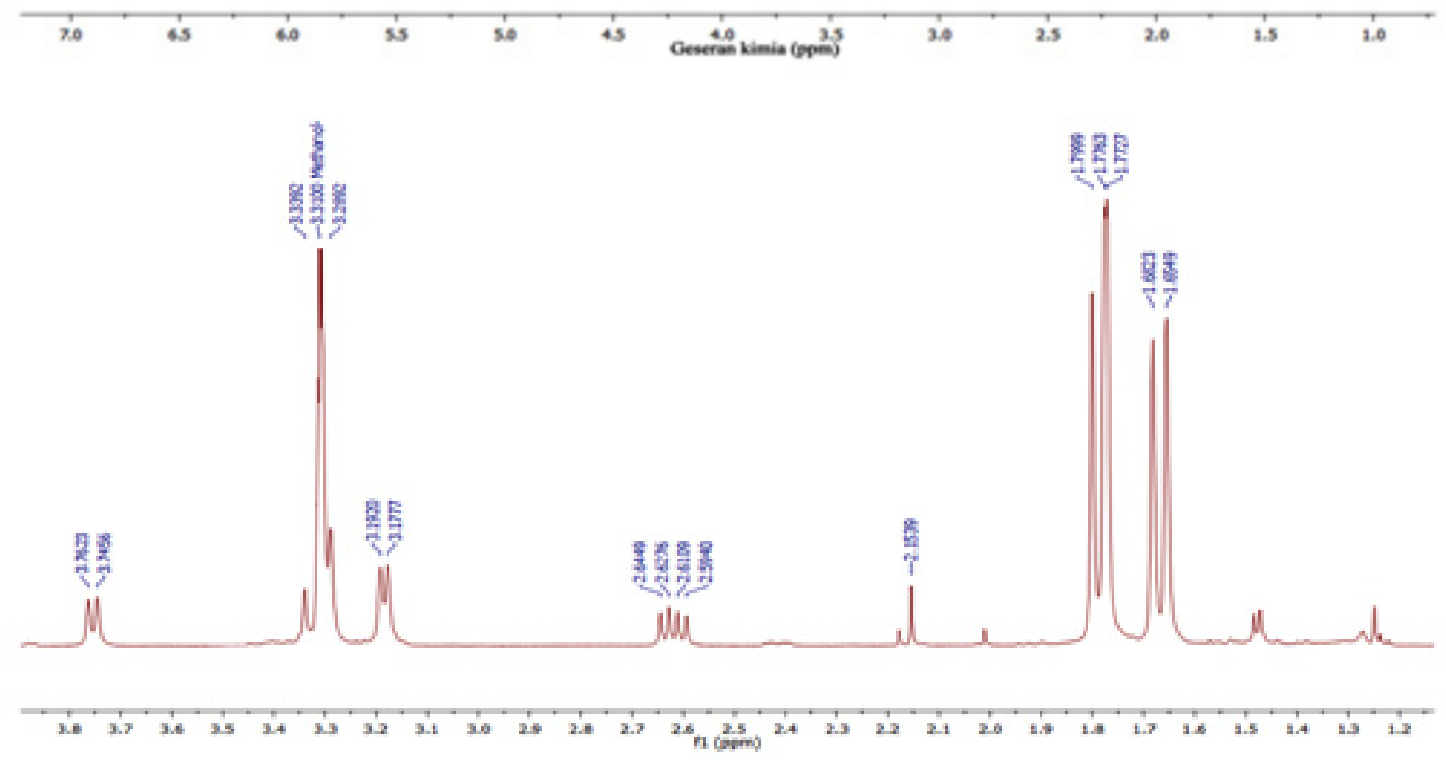
The high resolution mass spectrum shows a signal at $[\mathrm{M}+1]^{+} \mathrm{m} / \mathrm{z}$ 503. Based on this value, compound 1 is known to a xanthone derived from a flavone with $B$ ring quinonly structrured with a frame similar to artonin $\mathrm{O},[\mathrm{M}+]=502$ with molecular formula of $\mathrm{C}_{30} \mathrm{H}_{30} \mathrm{O}_{7}$.

Carbon shifts at $\delta 154.2 ; 156.9 ; 157.0$; 159.7 ; and $163.9 \mathrm{ppm}$ indicated the aromatic carbons which bound oxygen. The signals at $\delta$ 94.3; 105.6; 113.3; 118.1; 122.7; 132.3; and 145.5 ppm indicate the presence of aromatic $\mathrm{C}=\mathrm{C}$, while signals $\delta 36.7$ and $22.9 \mathrm{ppm}$ indicate the aromatic $\mathrm{C}$-C. The shifts at $\delta 112.9 ; 121.6 ; 123.3 ; 132.1 ; 133.8$; and 142.7 ppm assigned as $\mathrm{C}=\mathrm{C}$ aliphatic. The signals at $\delta 17.9$; 18.0; 21.8; 22.2; 22.3; 25.9; and 25.9 are assigned for $\mathrm{C}-\mathrm{C}$ aliphatic ${ }^{7}$. Based on the data obtained, then the ${ }^{13} \mathrm{C}$ NMR data of compound 1 are suitable for artonin $\mathrm{O}$.

The analyses on the ${ }^{13} \mathrm{C} N M R$ are supported by the ${ }^{1} \mathrm{H}$ NMR of compound 1 (Fig. 3)

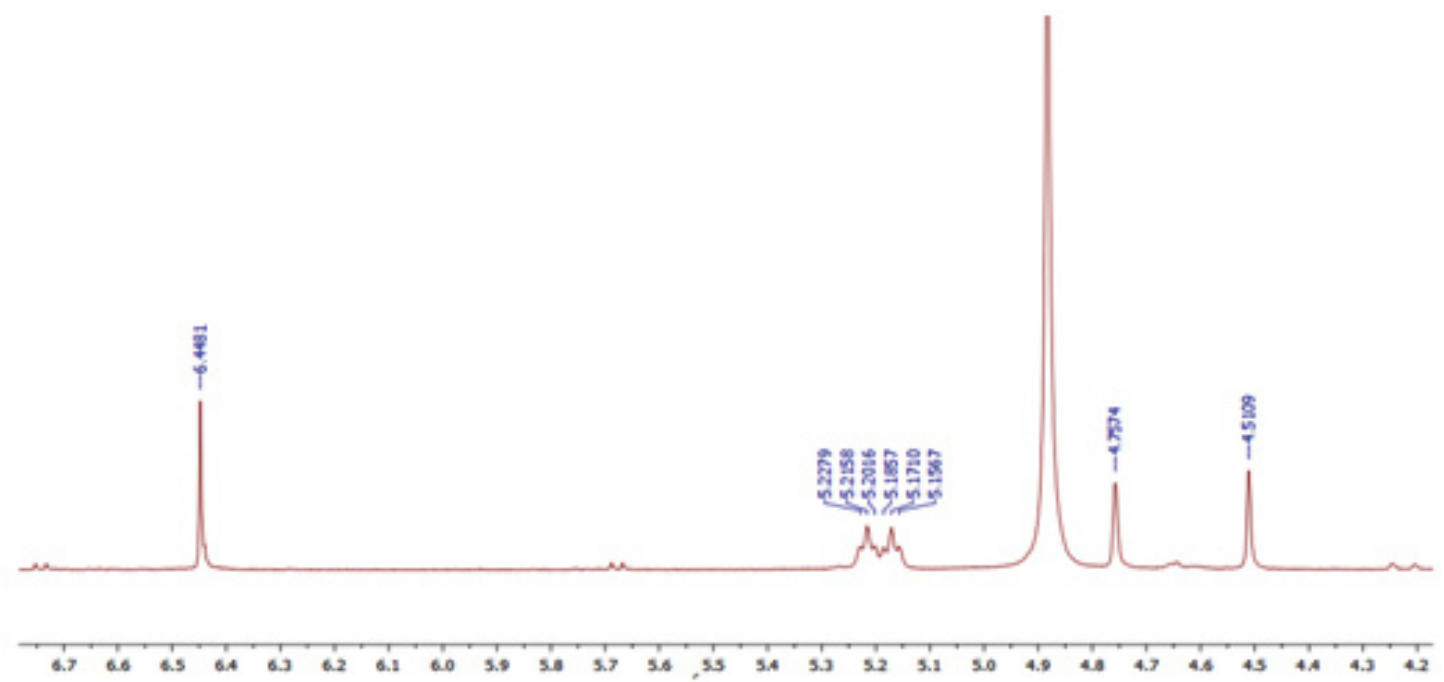

Fig. 3: ${ }^{1} \mathrm{H}$ NMR spectrum of compound 1 (a) normal spectrum and (b) enlarge spectrum

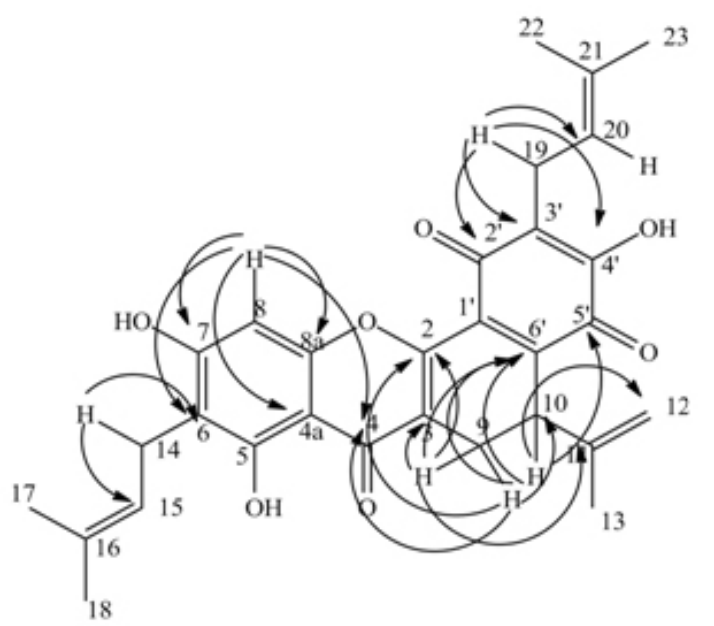

Fig. 4: Some important HMBC correlation of compound 1 which shows some chemical shifts and coupling constants of cyclic protons of the ABX type. These signals are $\delta 2.62(1 \mathrm{H}, \mathrm{d}, J=8.3 \mathrm{~Hz}, \mathrm{H}-9 \mathrm{a}), 3.33$ $(\mathrm{H}-9 \mathrm{~b})$ (covered by solvent signal), and $3.75(1 \mathrm{H}, \mathrm{d}$, $J=8.3 \mathrm{~Hz}, \mathrm{H}-10$ ).

There are also some aromatic proton signals at d $6.46(1 \mathrm{H}, \mathrm{s}, \mathrm{H}-8)$ and some proton signals at $\mathrm{d} 1.65 ; 1.68$ (each at $3 \mathrm{H}, \mathrm{s}, \mathrm{CH}_{3}-17$, and $\left.\mathrm{CH}_{3}-22\right) ; 1.78\left(3 \mathrm{H}, \mathrm{s}, \mathrm{CH}_{3}-18\right)$; and $1.80\left(3 \mathrm{H}, \mathrm{s}, \mathrm{CH}_{3}-\right.$ 13); $3.18(2 \mathrm{H}, \mathrm{d}, \mathrm{J}=7.1 \mathrm{~Hz}, \mathrm{H}-19)$ and $3.34(2 \mathrm{H}, \mathrm{d}$, $J=6.71 \mathrm{~Hz}, \mathrm{H}-14) ; 5.17(1 \mathrm{H}, \mathrm{m}, \mathrm{H}-15)$ and 5.21 $(1 \mathrm{H}, \mathrm{m}, \mathrm{H}-20)$ which assigned the presence of two 3,3-dimethylalyl groups attached at C-6 and C-3'.

Furthermore, the proton signals of isoprophenyl groups appeared at $\mathrm{d} 1.78\left(3 \mathrm{H}, \mathrm{s}, \mathrm{CH}_{3}-\right.$ 
Table 2: Comparison of ${ }^{13} \mathrm{CNMR}$ and ${ }^{1} \mathrm{H}$ NMR sepctra data compound 1 with artonin $\mathrm{O}^{3,8}$

\begin{tabular}{|c|c|c|c|c|}
\hline \multicolumn{3}{|c|}{${ }^{13} \mathrm{C}$ NMR, $\delta(\mathrm{ppm})$} & \multicolumn{2}{|c|}{${ }^{1} \mathrm{H}$ NMR, $\delta(p p m)$} \\
\hline No C & $\begin{array}{l}\text { Artonin } \mathrm{O} \\
\left(\mathrm{CD}_{3} \mathrm{OD}\right)\end{array}$ & $\begin{array}{l}\text { Compound } 1 \\
\left.\text { (CD }{ }_{3} \mathrm{OD}\right)\end{array}$ & $\begin{array}{l}\text { Compound } 1 \\
\left(\mathrm{CD}_{3} \mathrm{OD}\right)\end{array}$ & $\begin{array}{l}\text { Artonin O } \\
\left(\mathrm{CD}_{3} \mathrm{OD}\right)\end{array}$ \\
\hline 2 & 157.2 & 157 & & \\
\hline 3 & 118.1 & 118.1 & & \\
\hline 4 & 181.7 & 181.6 & & \\
\hline $4 a$ & 105.6 & 105.6 & & \\
\hline 5 & 159.7 & 159.7 & & \\
\hline 6 & 113.4 & 113.3 & & \\
\hline 7 & 164 & 163.9 & & \\
\hline 8 & 94.4 & 94.3 & $6.46(1 \mathrm{H}, \mathrm{s})$ & 6.45 \\
\hline $8 a$ & 157 & 156.9 & & \\
\hline $1{ }^{\prime}$ & 132.5 & 132.3 & & \\
\hline $2^{\prime}$ & 184.6 & 184.6 & & \\
\hline $3^{\prime}$ & 122.5 & 122.7 & & \\
\hline $4^{\prime}$ & 155.1 & 154.2 & & \\
\hline $5^{\prime}$ & 183.3 & 182.9 & & \\
\hline $6^{\prime}$ & 145.6 & 145.6 & & \\
\hline \multirow[t]{2}{*}{9} & 22.9 & 22.9 & $\begin{array}{c}2.62(1 \mathrm{Ha}, \mathrm{q}, \mathrm{J}=8.3 \mathrm{~Hz}) \text {. } \\
3.33(1 \mathrm{Hb}, \text { covered by } \\
\text { solvent signal) }\end{array}$ & 2.61 \\
\hline & & & $3.75(1 \mathrm{H}, \mathrm{d}, \mathrm{J}=8.3 \mathrm{~Hz})$ & 3.35 \\
\hline 10 & 36.8 & 36.7 & $4.75(1 \mathrm{Ha}, \mathrm{s})$ & 3.75 \\
\hline 11 & 142.8 & 142.7 & $4.51(1 \mathrm{Hb}, \mathrm{s})$ & \\
\hline \multirow[t]{2}{*}{12} & 112.9 & 112.9 & $1.77(3 \mathrm{H}, \mathrm{s})$ & 4.75 \\
\hline & & & $\begin{array}{l}3.34(2 \mathrm{H}, \text { covered } \\
\text { by solvent signal) }\end{array}$ & 4.54 \\
\hline 13 & 21.8 & 21.8 & $5.17(1 \mathrm{H}, \mathrm{t}, \mathrm{J}=7.3 \mathrm{~Hz})$ & 1.77 \\
\hline 14 & 22.2 & 22.2 & & 3.34 \\
\hline \multirow[t]{2}{*}{15} & 123.3 & 123.3 & $1.65(3 \mathrm{H}, \mathrm{s})$ & 5.17 \\
\hline & & & $1.78(3 \mathrm{H}, \mathrm{s})$ & \\
\hline 16 & 133.7 & 133.8 & $3.18(2 \mathrm{H}, \mathrm{d}, \mathrm{J}=7.1 \mathrm{~Hz})$ & \\
\hline 17 & 25.9 & 25.9 & $5.21(1 \mathrm{H}, \mathrm{m})$ & 1.65 \\
\hline 18 & 17.9 & 17.9 & & 1.77 \\
\hline 19 & 22.3 & 22.3 & $1.68(3 \mathrm{H}, \mathrm{s})$ & 3.19 \\
\hline 20 & 121.8 & 121.6 & $1.80(3 \mathrm{H}, \mathrm{s})$ & 5.21 \\
\hline 21 & 132.2 & 132.1 & & \\
\hline 22 & 25.9 & 25.9 & & 1.67 \\
\hline 23 & 18 & 18 & & 1.8 \\
\hline
\end{tabular}


Table 3: The measurement result of inhibition zone from artonin $O$ against $B$. subtilis with incubation time of 24 hours

\begin{tabular}{lccc}
\hline Compound & \multicolumn{3}{c}{ Inhibition Zone (diameter, $\mathbf{~ m m}$ ) } \\
& $\mathbf{0 . 3} \mathbf{~} \mathbf{g} / \mathbf{d i s c}$ & $\mathbf{0 . 4} \mathbf{~} \mathbf{g} / \mathbf{d i s c}$ & $\mathbf{0 . 5} \mathbf{~ m g / d i s c}$ \\
\hline Artonin O & 7 & 7.5 & 8.5 \\
Amoxicilline (+) & 20 & 22 & 22.5 \\
Methanol (-) & 0 & 0 & 0 \\
\hline
\end{tabular}

23) and signals at $d 4.51 ; 4.75$ (each corresponds to $1 \mathrm{H}, \mathrm{s}, \mathrm{H}-12$ ). The comparisons of ${ }^{13} \mathrm{C}$ NMR and ${ }^{1} \mathrm{H}$ NMR spectra for compound 1 with data on literature for artonin $\mathrm{O}^{3,8}$ are tabulated at Table 2.

The deduction was also supported by the HMBC spectrum as shown in Fig. 4.

\section{Bioactivity test}

Artonin $\mathrm{O}$ has shown to have antibacterial activity toward the growth of $B$. subtilis by the formation of inhibition zone at all concentrations of $0.3 ; 0.4$ and $0.5 \mathrm{mg} / \mathrm{disc}$, with inhibition zone diameters were $7,7.5$ and $8.5 \mathrm{~mm}$, respectively. While amoxicilline used as control positive with concentrations of .05; 0.10 ; and $0.15 \mathrm{mg} /$ disc, the inhibition zone diameter measured were 20,22 , and $22.5 \mathrm{~mm}$, respectively.

Based on the data obtained, it is known that the higher the concentration of the sample used, the higher the inhibition zone observed, although in overall, the positive controls have also been observed to inhibit much higher. The functional groups of compound 1 that play role on the antibacterial activities are hydroxyl group, carbonyl and isopropenyl. These groups are able to form hydrogen bond with protein from the bacteria cell showing a specific interaction. According to Davis and Stout $^{9}$, in the antibacterial activity, if the inhibition zone diameter observed is $5 \mathrm{~mm}$ or less, it is categorized as weak activity; $5-10 \mathrm{~mm}$ as medium activity, $10-19$ as strong activity and $20 \mathrm{~mm}$ or more categorized as very strong activity. Based on the data obtained in this research, therefore artonin $\mathrm{O}$ is categorized as medium activity in the antibacterial activity test.

\section{CONCLUSIONS}

From the root wood of $A$. rigida has successfully been isolated a xanthone compound, artonin $O(1)$ showing medium antibacterial activity towards $B$. subtillis.

\section{ACKNOWLEDGMENTS}

The authors are grateful to Directorate of Research and Community Services, Directorate General of Higher Education, The Ministry of Research, Technology and Higher Education, Republic of Indonesia that provide fund for this project to be undertaken through Hibah Kompetensi (Competitive Research Grant) Scheme 2016 with contract number of 78/UN26/8/LPPM/2016, 13 April 2016.

\section{REFERENCES}

1. Suhartati, T.; Achmad, S.A.; Aimi, N.; Hakim, E.H.; Kitajima, M.; Takayama, H.; Takeya, K. Fitoterapia 2001, 72, 912-918.

2. Suhartati, T.; Yandri; Hadi. S. Eur. J. Sci. Res. 2008, 23 (2), 330-337.

3. Suhartati, T. Phenol of Some Species of Jack Fruit Plant in Indonesia (Dissertation). ITB.
Bandung, 2001. (in Indonesian)

4. Lin, C.-N.; Shieh, W.-L.; Jong, T.-T., Phytochemistry 1992, 31(7), 2563-2564.

5. Sultanbawa, M.U.S.; Surendrakumar, S., Phytochemistry 1989, 28(2), 599-605.

6. Hano, Y.; Inami, R.; Nomura, T. Heterocycles 1993, 35 (2), 1341-1350. 
7. Jacobsen, N.E. NMR Spectroscopy Explained : Simplified Theory, Application and Examples for Organic Chemistry and Structural Biology. John Wiley \& Sons. England. 2007,
8. Suhartati, T.; Achmad, S.A.; Aimi, N.; Hakim, E.H., J. Mat. Sains, 1999, 4(2), 178-184.

9. Davis, W.W.; Stout, T.R. Appl. Microbiol. 1971, 22 (4), 659-665. 